\title{
A New Definition of Geography
}

\section{H. W. Fairbanks}

To cite this article: H. W. Fairbanks (1919) A New Definition of Geography, Journal of Geography, 18:5, 185-188, DOI: 10.1080/00221341908984807

To link to this article: http://dx.doi.org/10.1080/00221341908984807

册 Published online: 22 Feb 2008.

Submit your article to this journal $2 \pi$

III Article views: 11

Q View related articles $₫$ 
than the knowledge of the map; that it is much more than industry and commerce; that it has for its special province the relations between men and the physical influences in which they live, the relation of all life to its physical environment; if we could get the vision that "modern geography is characterized by the search for truth in the field of science, and even more by the desire to render its truths of service to mankind; if we could only see that its subject matter touches the life and welfare of the human race more intimately and fundamentally than that of any other science; that geography possesses in itself high eultural and disciplinary value and contributes eminently to good citizenship," we should awake at the call of the new day and prepare our boys and girls for the new era now being ushered in. If we are wise, we shall examine our course of study carefully, throw out non-essentials, and elevate the science of geography to the proud place it deserves in the general education of the future American citizen.

\section{A NEW DEFINITION OF GEOGRAPHY* \\ By H. W. FAIRBANKS, \\ Berkeley, Cal.}

It has long been the writer's opinion that the subject of elementary school geography falls far short of accomplishing what it might accomplish-is in fact a practical failure. This he believes to be attributable partly to the obscurity that invests the whole matter of content and partly to the absurdities and inconsistencies involved in the methods of instruction commonly employed.

\section{Present State of Geography}

One cannot judge of the real condition of geography instruction by the excellent ideas now and then voiced by some progressive teacher in one of the educational journals. These articles

* This article shonld be compared with Professor Fenneman's Presidential Address to the Association of American Geographers, 1918, abstracted in the April number of the Journal. The trend of thought is essentially similar: Professor Fenneman speaks in more general terms. Dr. Fairbanks has the teaching of school geography especially in mind.-EDIT. NOTw. 
have little in common with the practical application of the subject in the great majority of schools.

If, in the attempt to frame a clear conception of what school geography is commonly held to consist of, one were guided by the material presented in the textbooks in use and by the courses of study of the leading city and practice schools in the United States, one would be forced to the conclusion that the subject consists of a little of everything which cannot conveniently be placed elsewhere. And one could scarcely be blamed for agreeing with $G$. Stanley Hall who, some years ago, said that geography is a hodgepodge of all the sciences and should be split up and its materials placed in their appropriate departments.

At the present time, with the ever-growing struggle among new subjects for a place in the curriculum, there is no longer room for a conglomerate geography. The tendency of late has been to cut down the time given to the subject in the upper grammar grades, owing doubtless to its questionable value as compared with other subjects.

NeEd of Reform

Two fundamental conditions appear to be accountable for the present lamentable situation. The first is that very few, if any, teachers have a clear idea of the real nature of geography. Floating round in their minds is a vague, indefinite notion of geography as a study of the earth and man; but if they were asked just what should be placed in the geography course and what should be excluded from it, no two of them, we may be sure, would be found in agreement. The second of the causes referred to is the nearly universal failure to organize the work along the lines, or to use the methods, which a sound pedagogy demands.

Now is the time of all times when we need to introduce into school geography a universal viewpoint. Our country is coming into more intimate contact with other lands and peoples than ever before. We need to make geography more real and vital in order that the children now growing up may be able to take their parts intelligently in the new community of nations.

In the present article the writer purposes to offer a new definition of geography-one which he hopes will avoid the pitfalls of the older definitions and will carry further the modern conception 
that geography is not a study or memorizing of facts, but a study of the relations existing among facts. In a later article he will consider some of the other reasons for the failure of school geography.

Geography was formerly held to be the science which treats of the earth as the home of man. Its methods were almost wholly descriptive. It lacked a unifying principle, and its boundaries were indistinct.

More recently geography has been defined in much the same manner as before, except that the idea of cause and effect has gradually grown in importance. Modern geography places less emphasis upon mere statements of facts about the earth and man, and more upon the relations existing among these facts. Howcver, it exhibits little more unity or coherence than did the old geography. Owing to a wrong point of view the inner unity through which facts become geographic is not fully realized.

\section{The New Geggraphy ${ }^{1}$}

The new conception of the subject does not admit that an enumeration of facts about the earth, or a mere description of them, constitutes true geography. Facts thus presented are held to be mere matters of information. The new view holds that there are no facts or phenomena which are the exclusive property of geography. The subject has, therefore, a different basis from all other branches of learning except philosophy. The study of nature shows that no fact or phenomenon exists by itself independent of or unconditioned by others.

(1) Every phenomenon may be studied from the point of view of its own inherent properties, for which purpose it is isolated as far as possible from its associations. This method of approach gives us the various sciences.

(2) Every phenomenon may be studied from the point of view of the relationship which exists between it and other phenomena. This synthetic study of phenomena as they occur in nature is the only true approach to the study of geography.

The point from which we view a fact or phenomenon determines, then, whether or not it should be included in a geographic

1 Western Joum. of Education, April, 1918. 
discussion. Isolation of any phenomenon for the purpose of study takes it out of its natural relationship or environment. This causes its geographic aspect to disappear, and it becomes material for one of the other sciences.

\section{True Geography}

True geography is, then, an attempt to explain the phenomena of the material world in their natural relations or settings.

Since all the phenomena of the physical world are more or less mutually conditioned, working together to make the world as we know it and having while in this relationship different significance than when isolated, we may consider the world as an organism with functioning parts. The full significance of an organism can be understood only when it is alive and its parts are performing their natural functions. When it is destroyed and its parts are separated, it ceases to be an organism. The study of the world as a living organism is the proper province of geography. Since the materials of geography include all phenomena in their natural or world relations, we may therefore define geography as the science which seeks to understand the world as a living organism.

\section{SEAPORTS-A STUDY, ILLUSTRATED BY LOS ANGELES}

By JEHIEL S. DAVIS

High School, Preseott, Ariz.

A harbor may be defined as a haven for ships which does not necessarily include a town. A port is a commercial landing place (a point where goods are transshipped from land to sea or vice versa), a city or town usually including a harbor. Mollendo, Peru, is a port without what is usually understood as a harbor for it is a commercial landing place with no haven, and goods must be lightered to the ships. Even in this case, it should be noted, a small island offers a certain amount of shelter to shipping. This natural feature, slight as it is, calls to mind the invidiousness 